\title{
RESILIENCE IN THE SWEDISH HEALTHCARE SYSTEM
}

\author{
Patrik Hidefjäll ${ }^{1}$ \\ 1) National Board of Health and Welfare, Sweden
}

\begin{abstract}
Background: Swedish healthcare has become increasingly under strain with problems to recruit and retain personnel, decreasing production and productivity as well as increasing queues. This more demanding situation raised the question if it also would affect the healthcare system's ability to deal with disruptions. The ability of a healthcare system to handle both regular and extraordinary disruptions is essential to ensure care of citizens under varying conditions and trust in the system.
\end{abstract}

Purpose: to assess the ability of the Swedish healthcare system to handle both regular and extraordinary disruptions in a short- and long-term perspective.

Theory: a resilience-engineering framework of four system functions: monitoring, response, anticipation and learning, was used.

Methods: quantitative (official statistics) and qualitative methods were combined. DRG statistics determined production and the productivity of Swedish healthcare regions. Document studies, interviews and workshops helped understand issues qualitatively.

Results: Swedish healthcare has an adequate ability to respond to short-term extraordinary disturbances, but has more problems in handling regular challenges in operative care. Key reasons for these problems were insufficient monitoring and learning; as evidenced by problems to match capacity to needs and difficulty in realizing structural change towards a healthcare system based around primary care.

Conclusions: Swedish healthcare exhibits a typical pattern in many organizations in which focus on short-term pressures crowds out longer-term strategic issues of system restructuring.

(C) 2019 Patrik Hindefjäll. This is an Open Access article distributed under the terms of the Creative Commons AttributionNonCommercial 4.0 International License (http://creativecommons.org/licenses/by-nc/4.0), permitting all non-commercial use, distribution, and reproduction in any medium, provided the original work is properly cited.

ISBN: 978-91-88898-41-8

DOI: https://doi.org/10.15626/rea8.11 


\section{INTRODUCTION}

Swedish healthcare has become increasingly under strain with problems to recruit and retain personnel, decreasing production and productivity as well as increasing queues. This increasingly demanding situation raised the question how the healthcare system's ability to deal with disruptions may be affected by operating near its effective capacity. The ability of a healthcare system to handle both regular and extraordinary disruptions is essential to ensure care of citizens under varying conditions, but also to uphold trust in the healthcare system.

Swedish healthcare is a decentralized system where funding and organiza-tion of care is the responsibility of the 21 regional county councils (regions). The primary source of funding is via county council and municipality proportional income taxes [1]. In addition to the regions, there are 10 national government agencies that help ensure that health and social care is performed according to national laws, i.e. safe, accessible, based on updated knowledge and the principles of human dignity, needs and solidarity, and cost-effectiveness. These government agencies provide nationally shared structures such as the hospital based patient register since 1987 and the Diagnosis Related Group (DRG) system since 1995, both provided by the National Board of Health and Welfare [2].

In order to manage larger disruptions and challenges the regions may need to cooperate with each other and designated state agencies. In the case of major incidents, the regions are, according to the healthcare act (2017:30), required to have a special emergency organization in place. How this emergency organization should be organized is defined in the Swedish regulation SOSFS 2013:22 [3].

\section{THEORETICAL BACKGROUND}

A system that can adjust its performance prior to, during, or following events (changes, disturbances, and opportunities) to sustain required operations under both expected and unexpected conditions has been termed resilient [4]. The concept of resilience grew out of a discussion in the patient-safety research community that had hitherto focused on understanding the sources of error, but instead offered a different perspective by focusing on how things go right. Resilience was seen as a more promising concept than the traditional safety work that had focused on identifying causes of error and tried to eliminate them, but had not been able to reduce the actual frequency of errors [5]. Traditional safety work, termed Safety-I analyzed outcomes in relations to defined guidelines, operating procedures and standards whereas the Safety-II approach tried to understand how work was actually done and adjusted under constantly varying conditions [6].

The worldview behind the resilience concept assumes reality to be com-plex and emerging and never possible to fully describe in a guideline or standard. Therefore the performance of a system always requires oversight, adaptations, preparations and learning to stay resilient. These four related functions of a system are therefore assumed requisite of a resilient system performance:

(1) monitoring or exploring the system's function and performance,

(2) responding or reacting to events or conditions,

(3) anticipating or foreseeing future events and conditions, and

(4) learning or reorganizing system knowledge [4, 7]. 


\section{PURPOSE OF THE STUDY}

The purpose of the study was to assess the Swedish healthcare system's ability to handle both regular and extraordinary disruptions and incidents in a short- and long-term perspective. This purpose can be expressed in the following four related research questions:

- How well is forecasting of future healthcare challenges done by Swedish state agencies and utilized by the Swedish regions

- How well is the healthcare system monitored and needs and capacity matched and managed at a strategic regional healthcare level

- How well are routines for responding to disturbances short-term at regional level working

- How well does regional healthcare systems learn and adapt to situations of disturbance

\section{METHODS AND MATERIALS}

This paper is based on a report of the author for the National Board of Health and Welfare to investigate the capacity of Swedish healthcare to handle major incidences [8].

The four research questions all relate to the resilience of the Swedish healthcare system and therefore also to the time dimension. The first question of forecasting is primarily addressing the time perspective of plus five to twenty years. Material used to answer this research question has mainly consisted of governmental agency forecasts during the period from 1995-2018.

The question of monitoring healthcare systems at regional level primarily covered a time span of 1 to 3 years and was addressed by interviews with management in charge of healthcare in 11 of the 21 respective regions and by independent analyses of official statistics sources. All major regions in all geographical parts of Sweden were interviewed covering $3 / 4$ of the Swedish population. DRG statistics were used to determine production and the productivity of Swedish healthcare regions over the time period of 2012-2018. Other official statistics sources were used to understand the develop-ment of various healthcare resources (financial resources, key personnel categories, number of beds, IT-infrastructures deployed etc.) over the same time period.

The question of how well the healthcare system responded to major dis-turbances was divided into "ordinary" disturbances and major emergency incidents. Management of ordinary disturbances are handled as part of capacity management within the ordinary clinics of a hospital whereas major incidents are usually, initially handled by a designated duty officer and a particular disaster medicine organization. In the case of handling ordinary disturbances as part of capacity management the time span varies from one year down to daily management. In the case of major emergency incidents the time span instead relates to minutes. The material used to analyze man-agement of ordinary disturbances consisted of a systematic review of official documents on the topic of "produktions- och kapacitetsplanering" published on the webpages of the respective regions, interviews with experts in capacity management in the regions and two in-depth case studies of two regions (Gavleborg and Orebro). Interviews with designated duty officers in 15 of the 21 regions and additional documents describing their disaster planning organizations were sources used to determine the ability to handle major emergency incidents.

Learning and resulting changes in the healthcare system relate to a time perspective of more than 3-5 years. Learning is seen as "organizational", i.e. an institutional, social process that involves changes in las regulations, norms, routines, standards, control variables, competence and available resources [7,9]. The analysis of the ability of the healthcare system to learn from 
major events was based on document studies of policies, reports that were com-pared with official statistics to determine if identified problems in reports that were addressed in policies also materialized as changes in various indicators taken from official statistics.

\section{ANTICIPATING SYSTEM CONDITIONS AND CHALLENGES}

How key decision-makers in an organization view the future impacts what parameters of an organization to monitor and how the organization is con-trolled. Parameters that are long-term and predictable can also be part of forecasting, in contrast to probable parameters that may be short-term and unpredictable and must be monitored and responded to. Parameters that are forecasted are usually the system's access to critical resources and future needs that the system is expected to meet in the future. To be more specific, availability to key personnel groups such as nurses and physicians and expectations of care needs based on demographic extrapolation are aspects that usually are part of forecasts to support the healthcare system. This is also the case in Sweden.

All government related forecasts of healthcare since the 1990s were based on demographics and foresaw increasing healthcare needs and difficulties in financing healthcare without increasing taxation, or an unlikely constant productivity improvement [10-13]. However, an especially influential forecast by the National Board of Health and Welfare predicted 2 percent annual reduction in length of stay and hospital bed needs during the whole forecasting period from 1996-2011 [14]. This forecast was also confirmed by a later forecast report by the Swedish Association of Local Authorities and Regions in which it was stated that the average length of stay had become 25\% shorter between 1995 and 2005 and the number of beds 2005 half of those available in 1995 [12]. Despite that later forecasts realized that there had been extraordinary productivity improvements during the 1990s, driven by structural change and developments of minimally invasive surgery and endovascular methods $[12,13,15,16]$ management at the healthcare regions became accustomed to reduce the number of beds as a means to reduce costs and ensure a budget in balance. Also the forecasts that the National Board of Health and Welfare were regularly publishing since 2001 about the availabil-ity and need for various health professions [17], were, as mentioned by an interviewee at one region, more read as a trend indicator, rather than used as material input for more detailed local planning of healthcare personnel recruitment and retainment. The forecasted deficiency of various healthcare professions such as physicians and nurses was however followed by the Swedish government and led to more resources made available to expand the number of students at the Universities to counter forecasted deficiencies.

In addition to the general government forecasts that covered care needs and availability of healthcare personnel work was initiated by the National Board of Health and Welfare in cooperation with the Regions to prepare the healthcare system for major incidents and disasters [18]. A new law was enacted 2008 that covered Swedish disaster medicine efforts abroad [19] that in turn led to a new guidance document for handling of major incidents and disasters [3].

\section{MONITORING SYSTEM PERFORMANCE, ITS NEEDS AND CAPACITIES}

The supply and demand for resources that take long time to develop and are critical to a system's performance such as new hospitals, specialist nurses and physicians need to be forecasted. In addition to long-term forecasting there is a need to monitor how these forecasts unfold and adjust capacity to faster occurring qualitative variation in demand for healthcare. Such variation can emanate from various sources such as new laws and regulation, norms, standards, medical or technological innovation or larger socio-economic challenges. 
The results of interviews conducted with 11 regions showed that very few were actively monitoring and matching needs and capacity on a strategic, regional level. The larger regions and some minor regions were monitoring factors that influence demand for healthcare, such as political, demographic and socio-economic indicators, but very seldom there was a corresponding, explicit capacity matching of identified needs on a regional level. In the larger regions pharmaceutical and sometimes medical technology develop-ments are monitored on a three year horizon that aids in the budget process. The most important resource allocating process in the Swedish regions is the annual budget process that is decided on a regional political level. Based on the overall budget and a three-year outlook, specific annual plans are devel-oped and agreed upon between the regional management and providers that may be private or publicly owned facilities. These annual budget contracts are usually adjusted based on previous contracts and the most recent out-comes, not based on a demand-driven systematic production planning process.

Interestingly, all regions announce on their websites that they have pro-grams for production and capacity planning that run on an operational level, but according to interviews, audit reports and the annual reports of the regions progress is very unevenly distributed among medical service provid-ing facilities [8] ${ }^{1}$. In depth case studies of surgical services in two Swedish regions showed the importance that managers at a tactical organizational level between the strategic regional level and the operational facility level were actively driving production and capacity planning in a long-term, systematic way on a fairly detailed level $[8,20]^{2}$. To achieve enduring performance effects, there is a need to not only monitor the inflow of patients in a very accurate way using IT-systems, but also to use patterns in this inflow over time on an annual, seasonally, weekly and daily cycle to schedule personnel and plan available capacity and to identify capacity bottlenecks and change work processes to alleviate them [20].

According to DRG-statistics covering Swedish specialized, hospital-based healthcare both production and productivity has declined during the studied period from 2012-2017. Productivity declined by 2.3 percent per year from 2012 to 2016 and production of in-patient care declined by 3 percent annually and hospital outpatient care declined by 0.6 percent per year during the period 2012-2017. In addition to declining production and productivity queues increased and availability indicators fell during the same period [8]. As the number of nurses and physicians per 1.000 inhabitants has remained stable during the same period the data combined indicate problems in matching capacity to demand in Swedish healthcare [8]. A key capacity limiting factor indicated in the report "Kapaciteten i sjukvården - att hantera kritiska lägen" was the number of hospital beds per capita that has been steadily decreasing over the years to become the lowest within the whole OECD area [21].

\section{RESPONDING TO SYSTEM DISRUPTIONS AND OPPORTUNITIES}

The steadily increasing strain on the Swedish healthcare caused parliamentary politicians to raise the question how this situation would affect the capacity to handle large scale disruption and disasters [22]. As described in the earlier section of this paper on anticipation of system challenges regional disaster preparedness organization for management of incidences and disasters was built up during the last 15 years, first described in the document SOSFS 2005:13, then in the updated document SOSFS 2013:22. The SOSFS 2013:22 regulation stipulates that every region need to have a dedicated duty officer scheduled on call $24 / 7$ and a prepared special

\footnotetext{
${ }^{1}$ Appendix 1 in the report "Kapaciteten i sjukvården - att hantera kritiska lägen" reviews all the published reports of Production and Capacity Planning on a regional level.

${ }^{2}$ Appendices 7 and 8 in the report "Kapaciteten i sjukvården - att hantera kritiska lägen"
} 
medical command and control organization that can be activated in case of major incidences or disasters.

Interviews with representatives of the disaster medicine organization in 15 regions indicated that all regions have a well-functioning crisis management organization for handling major incidences, with a dedicated duty officer scheduled on call $24 / 7$, as well as clear guidelines for when to activate special command and control organization at three different levels - increased state of readiness, reinforcement mode and disaster mode.

As the regulation SOSFS 2013:22 with a requirement to have a dedicated duty officer and a command and control structure in place came 2013, there has been a start-up period in the regions on how to implement the regulation. In some regions the dedicated duty officer is heavily involved in the coordi-nation of hospital beds, whereas in other regions it has been clearly decided that bed availability should be handled within the normal operative organization. Also the criteria for invoking medical command and control team have been differently interpreted in the regions.

Among the 11 interviewed regions there had been from 1800 designated duty officer cases in region Scania per year to only around 50 cases per year in region Västernorrland. During the same period 2015-2017 region Stock-holm had around 500 cases per year. Reasons for the large regional differ-ences may be the involvement in bed management, if the designated duty officer is involved in planned maintenance activities etc. A comparison of the share of cases related to bed management issues ranged from around 40 percent in region Scania down to 1-2 percent in many smaller regions. The number of cases when the medical command and control team had been activated also differed between the regions from 20 cases per year in region East Gothia to no case at all in region Västernorrland. Reasons for activation of the medical command and control team could be electricity or IT-infrastructure disorders, fires, traffic accidents, storms, flooding, refugee flows, large sports-, political or cultural events as well as lack of hospital beds.

In the interviews with regional representatives of the crisis management organization it was clear that when major incidents happened the designated duty officer was always responding fast with a capability to gain an overview of the situation, prioritize and initiate coordinating activities. In those cases when the medical command and control team was activated, prioritization of patients and calling in extra healthcare personnel and contact hospitals in other regions to expand the number of hospital beds was possible to meet the extra demand. Experience of more prolonged disasters with consequences for healthcare has been limited.

\section{LEARNING FROM EXPERIENCE TO ADAPT SYSTEM CAPACITIES}

A resilient organization needs to adapt and learn from experience. To be able to say that an organization has learned some visible changes in organizational behavior and performance has to be empirically verifiable. In the context of the four functions that determine resilience, learning means that other parameters are monitored, new response routines have been defined and new aspects are projected [4]. Learning on an organizational level needs to be manifested in institutional change in strategies, controlling, regulations, routines, attitudes etc., new competence and resources related to the institu-tional change [23, 24]. Learning will be discussed in relation to forecasting and planning of key resources such as personnel and hospital beds, and capacity management in healthcare.

Forecasting of competence needs in healthcare has been done by the Na-tional Board of Health and Welfare from 2005 until 2012 and communicat-ed to the regions and the national 
government. The first forecast in 2005 foresaw deficiencies of nurses already 2010 and of physicians in 2020. This led the Swedish government to expand resources to Universities for basic education of nurses and physicians and thereby to correct the forecasted deficiency. Around year 2010 deficiencies in specialist nurses became visible, indicating that the bottleneck of education was not the number of students, but the ability of the regions to provide practice positions where nurses and physicians could develop their specialization. The forecasts were only providing the supply of personnel and did not forecast the need for personnel, which was a clear limitation. The importance of identifying how the content of work among professions was changing, due to increasing sub-specialization, IT-systems, administration, healthcare quality registers that take away valuable time for seeing the patient, has also been mentioned to understand productivity development in healthcare [25]. The identifiable learning effects of healthcare personnel forecasts occurred within the gov-ernment rather than within the regions that did not analyze supply and demand for healthcare personnel in a longer term perspective, especially determinants of changing demand.

Figure 1. Example of Healthcare Personnel Forecasts

Forecasted number of educated physicians

Employed in Swedish healthcare

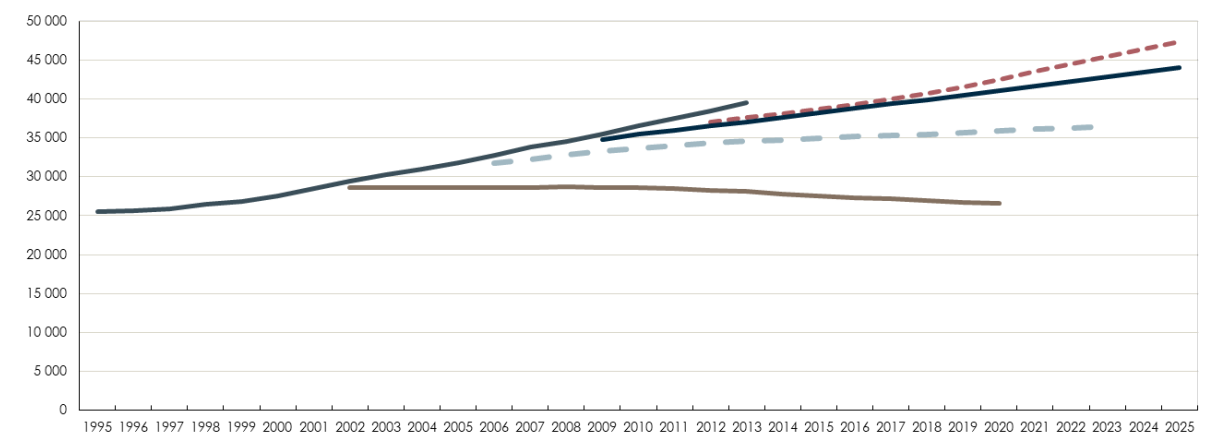

$\begin{array}{lll} & \text { Z Observerat } & \text { - } \\ \text { Source: NPS-register, socialstyrelsen 2009-2025 Prognos 2012-2025 } & - \text { Prognos 2008-2023 } & \text { Prognos 2005-2020 }\end{array}$

Another key resource in healthcare is the number of hospital beds available. During the 1990s the number of beds was rapidly reduced, based on reductions in average length of stay and forecasts were predicting bed time and average length of stay to continue decreasing with 2 percent per year at least until 2010 [14].

The data on which figure 2 are based show that the total number of bed days decreased by 1.6 percent and the average length of stay by 1.3 percent per year on average during the period 1998-2017. This is a slower decrease than the forecasted 2 percent by the National Board of Health and Welfare. However, the number of available hospital beds was on average reduced by 3 percent per year during 1998-2017. During the period from 2011 until 2017 average length of stay decreased by 0.3 percent per year whereas the number of available hospital beds decreased by 3.8 percent per year. The long-term trend of falling average length of stay that had been observed from the 1980s until 2010 was not upheld after 2010. One possible explanation for this was that the use of less invasive surgical methods and endovascular methods had already reached its maximum potential around 2010 and further reductions in length of stay had become minimal. However, Swedish healthcare management had during many years become accustomed to use the productivity potential of reducing hospital beds. This was also confirmed in several interviews with healthcare directors of the regions. Learning had become path-dependent and signs that this path was no longer viable were difficult to 
perceive [26]. In order to see these signs the given assumptions of the paradigm had to be questioned and double-loop learning had to occur [24].

In addition to identify system learning regarding access to critical resources it is important to identify how learning related to structural capacity increas-ing efforts and how capacity management occurs in the healthcare system. Several governmental reports since the 1990s have highlighted the need to strengthen primary care in Sweden [27-29], as a means to relieve specialized and acute hospital care and provide better continuity of care. Despite these ambitions, specialized care has increased and primary care has not strength-ened which indicates a lack of organizational learning and structural change in the Swedish healthcare system. Also the widespread ambitions to imple-ment systematic production- and capacity planning in the regions' healthcare provider has turned out to proceed much slower than planned. As an exam-ple the East Gothia region, that is regarded as one of the best regions in terms of production planning, started their efforts in 2008, but in 2016 only 71 percent of the providers had formally implemented production- and capacity planning [30].

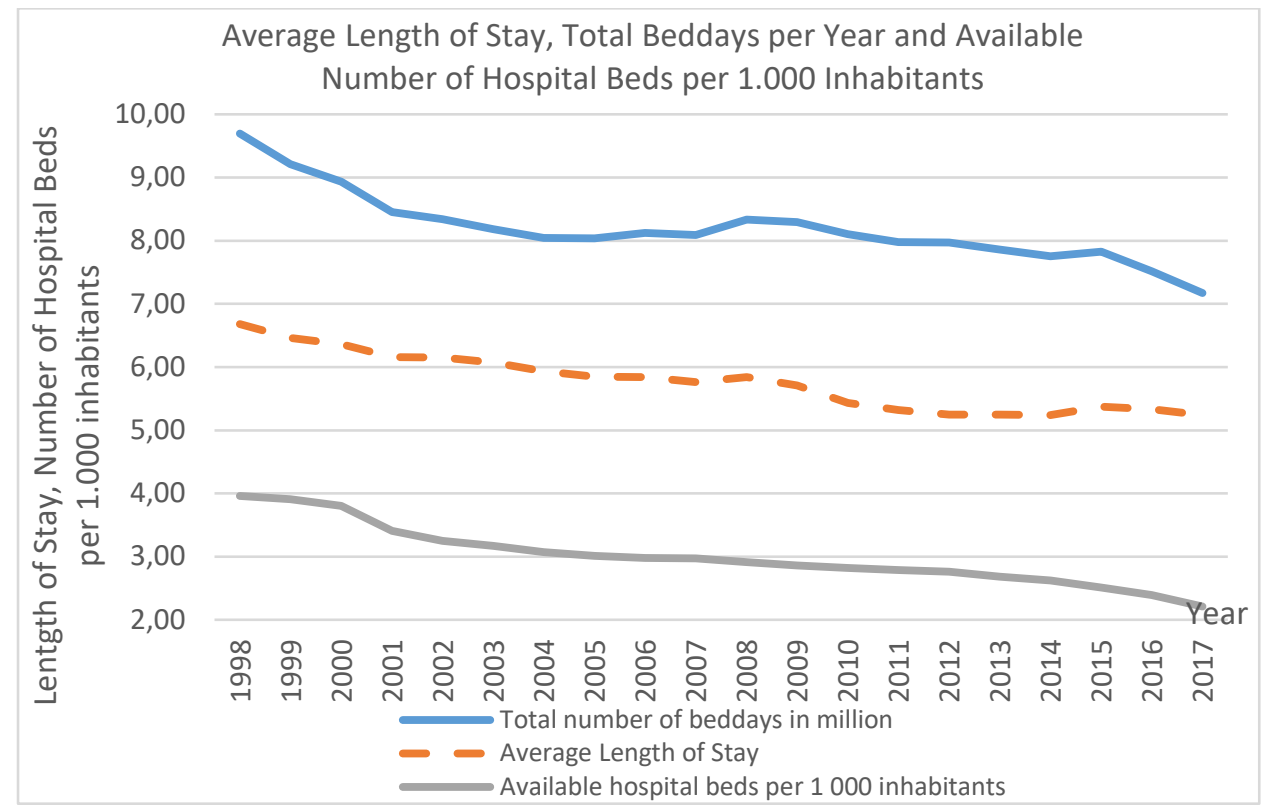

\section{DISCUSSION}

Swedish healthcare performance in terms of foresight, monitoring, respond-ing and learning, during the last 20 years, has been mixed. Government initiated and other national forecasts of demand for healthcare, finance needs and supply of workforce have helped prepare the mindset of regional managers of healthcare. There is widespread awareness of the challenges that demographic developments imply, however, the need for structural reforms to strengthen primary care has so far not been responded to. The importance of knowing and matching system needs and capacity well, to have oversight, is a weakness of the Swedish healthcare system. Responsibility for oversight is in many regions delegated to healthcare providers themselves and the overall needs assessments are often not matched by plans to develop corre-sponding capacity. This monitoring weakness also translates into a weak capacity planning with clear deficiencies in terms of available hospital beds and shortages of certain healthcare occupations. Despite that demanding situation for most healthcare providers, major incidences have been man-aged, by invoking medical command and control teams and reinforcing capacity. Finally, learning in Swedish healthcare has also been weak as the necessary reforms have not been undertaken, if we do not count the current efforts to create a stronger primary care that shall relieve specialized hospital care. 
By using the the four functions that, according to the theoretical approach, together create a resilient healthcare system it becomes clearer what are the key weaknesses that need improvement are, namely to improve monitoring and learning. Both these functions require not only better measurements of needs and the capacity to meet these needs, but foremost the ability to reallocate resources and build capacity in certain fields of healthcare, i.e. strategic change. Swedish healthcare is mainly controlled via short-term (1-3 years) budgeting.

\section{CONCLUSIONS}

The resilience-engineering framework, as suggested by Hollnagel and others, provides an overall analysis framework of how well a system is designed to handle both short-term and longer-term challenges. In the case of the Swedish healthcare system, this analysis indicates a focus on handling short-term challenges, but a weaker ability to handle the longer-term increasing strain on the system, by addressing key problems of capacity management, retaining of key personnel groups and structural change.

\section{REFERENCES}

[1] Anell A, Glenngard AH, Merkur S. Sweden health system review. Health systems in transition. 2012;14(5):1-159.

[2] Busse R, Geissler A, Aaviksoo A, Cots F, Hakkinen U, Kobel C, et al. Diagnosis related groups in Europe: moving towards transparency, efficiency, and quality in hospitals? BMJ (Clinical research ed). 2013;346:f3197. https://doi.org/10.1136/bmj.f3197

[3] Katastrofmedicinsk beredskap, SOSFS 2013:22 (2013).

[4] Hollnagel E. Resilience Engineering. http://erikhollnagel.com/ideas/resilienceengineering.html2016.

[5] Hollnagel E, Woods, D.D. \& Leveson, N.G. Resilience engineering: Concepts and precepts. Aldershot, UK: Ashgate; 2006. 397 p.

[6] Hollnagel E, Wears R., Braithwaite J. From Safety-I to Safety-II: A White Paper. In: University of Southern Denmark IfRHRI, editor. https://resilienthealthcare.net/wpcontent/uploads/2018/05/WhitePaperFinal.pdf2015. p. 43.

[7] Fairbanks RJ, Wears RL, Woods DD, Hollnagel E, Plsek P, Cook RI. Resilience and resilience engineering in health care. Joint Commission journal on quality and patient safety. 2014;40(8):376-83.

[8] Socialstyrelsen. Kapaciteten i sjukvården - att hantera kritiska lägen. Stockholm:

Socialstyrelsen; 2018. 150 p.

[9] Hollnagel E. Resilience Assessment Grid (RAG).

http://erikhollnagel.com/onewebmedia/RAG.pdf2016.

[10] 1996:163 S. Behov och resuser i vården - en analys. Stockholm: Socialdepartementet; 1996.

[11] Batljan I LM. Kommer det att finnas en hjälpande hand? Bilaga 8 till

Långtidsutredningen 1999/2000. Stockholm: Socialdepartementet; 2000. 126 p.

[12] SKL. Hälso- och sjukvården till 2030 - Om sjukvårdens samlade resursbehov på längre sikt. Stockholm2005.

[13] Socialdepartementet. Den ljusnande framtid är vård - delresultat från LEV-projektet.

Stockholm: Socialdepartementet; 2010.

[14] Socialstyrelsen. Medicinteknologisk utveckling och vårdkonsumtion inom sluten somatisk korttidsvård 1981 - 2011. Stockholm: Socialstyrelsen; 1996.

[15] Empati och high tech - Delresultat från LEV-projektet. Stockholm: Regeringskansliet; 2012 2012-11-14.

[16] SOU 2015:104, Långtidsutredningen 2015 - Huvudbetänkande. Stockholm: Regeringen; 2015 November 2015. 374 p. 
[17] Simonsson R. OJ, Åkesson G. En utvecklad hälso- och sjukvårdsorganisation. Örebro Läns Landsting; 201424 november, 2014.

[18] Socialstyrelsens föreskrifter och allmänna råd (SOSFS 2005:13) om fredstida katastrofmedicinsk beredskap och planläggning inför höjd beredskap. Stockholm:

Socialstyrelsen; 2005.

[19] Lag (2008:552) om katastrofmedicin som en del av svenska insatser utomlands, (2008).

[20] Uppföljning av hälso- och sjukvårdens tillgänglighet - Väntetider i akutsjukvården och fyra tematiska analyser, 2019. Stockholm: Socialstyrelsen; 2019. 142 p.

[21] OECD. OECD Health Statistics 2018 - Health Care Resources. In: OECD, editor. Paris, France2018.

[22] Regleringsbrev för budgetåret 2018 avseende Socialstyrelsen, 7 (2017).

[23] Säljö R. Lärande i praktiken - Ett sociokulturellt perspektiv. Stockholm: Norstedts Akademiska Förlag; 2000. 279 p.

[24] Argyris C. Organizational learning: a theory of action perspective. Schön DA, editor. Reading, Mass.: Reading, Mass. : Addison-Wesley; 1978.

[25] Vårdanalys. Ur led är tiden. Stockholm: Vårdanalys; 2013. Contract No.: 2013:9.

[26] Dosi, G. Technological pradaigms and tecnological trajectories. Research policy. 1982;11:147-62.

[27] Regering S. Regeringens proposition 1999/2000:149. In: Socialdepartementet, editor. Stockholm: Regeringskansliet; 2000.

[28] Effektiv vård SOU 2016:2. Stockholm: Statens offentliga utredningar; 2016 2016-01.

[29] God och nära vård - En primärvårdsreform. Stockholm: Statens Offentliga Utredningar; 2018.

[30] Årsredovisning 2016 - Region Östergötland. Linköping: Region Östergötland; 2017. 189 p. 